\title{
EFFICIENCY, ENDOGENOUS AND EXOGENOUS CREDIT RISK IN THE BANKING SYSTEMS OF THE EURO AREA*
}

\author{
José M. Pastor and Lorenzo Serrano**
}

\section{WP-EC 2000-17}

Correspondence to J.M. Pastor: Universitat de València. Depto. de Análisis Económico. Campus de los Naranjos, s/n. Avda. de los Naranjos (Ed. Departamental Oriental). 46011 Valencia. Tel.: 963821601 / E-mail: jose.m.pastor@uv.es.

Editor: Instituto Valenciano de Investigaciones Económicas, S.A.

First Edition October 2000.

Depósito Legal:V-4113-2000

IVIE working papers offer in advance the results of economic research under way in order to encourage a discussion process before sending them to scientific journals for their final publication.

* The authors wish to thank the Ivie for providing us with the data and for the financial support. The paper is part of the project PB98 SEC98-0895 of the DGCIT.

*** Universitat de València.. 


\title{
EFFICIENCY, ENDOGENOUS AND EXOGENOUS CREDIT RISK IN THE BANKING SYSTEMS OF THE EURO AREA
}

\author{
José M. Pastor and Lorenzo Serrano
}

\begin{abstract}
A B S T R A C T
The implantation of the Euro in the eleven of the EU has driven the big banks to expand their presence in other European countries, which may have negative consequences on their credit risk in view of the disadvantages involved in entering new markets. The aim of this paper is to analyse the efficiency and the credit risk of the banks of the most important countries of the Euro area, using a one-stage parametric stochastic procedure that allows us to identify whether the behaviour towards risk of the banks analysed was more cautious or more reckless during the period analysed. The results indicate that adjustments for risk are important in the case of profit efficiency but not in the case of cost efficiency.
\end{abstract}

Key words: Efficiency, European banks, credit risk, bad loans.

JEL: G15, G21

\section{R E S U M E N}

La implantación del Euro en once paises de la EU ha impulsado a los grandes bancos a expandir su presencia en otros países europeos. Este hecho puede tener consecuencias negativas sobre el riesgo de crédito en la medida en que penetrar en nuevos mercados implica actuar en desventajas comparativas con los competidores ya instalados. El objetivo de este artículo es analizar la eficiencia y el riesgo de credito de los bancos de los paises más importantes del área Euro utilizando un enfoque de una sóla etapa que nos permite identificar si el comportamiento frente al riesgo de lod bancos analizados fue más prudente o más arriesgado durante el periodo analizado. Los resultados indican que los ajustes por el riesgo importantes en el caso de la eficiencia en beneficios, pero no el caso de la eficiencia en costes.

Palabras clave: Eficiencia, bancos europeos, riesgo de crédito, morosidad.

JEL: G15, G21 


\section{INTRODUCTION}

The implantation of the Euro in eleven of the fifteen countries of the EU has meant the widening of business opportunities in markets situated beyond national frontiers. Indeed the adoption of a common currency, among other things, makes it easier for clients to compare banking products, allowing greater and better knowledge of the supply, thus favouring the penetration into new markets of banks traditionally dedicated to local business.

The strategies of the large EU banks, initiated several years ahead of the implantation of the Euro, were already moving in that direction: to expand their presence in other countries. However, penetrating new markets always involves acting at a comparative disadvantage to the already established banks. In this sense, their relative ignorance of the market, together with an excessive zeal to expand their market share, could produce either a wrong evaluation of credit risk, or easier acceptance of it, so that the problem loans of these European banks may increase for these reasons.

Of the few international studies ${ }^{1}$, most have concentrated on analysing the efficiency of the European banking systems without concerning themselves with the specific impact that these processes may have on problem loans and the influence of the latter on efficiency. Only Pastor (1999b) analyses the possible consequences of the Euro-driven opening-up to new markets on the efficiency and credit risk of the banking systems of the Euro area.

The efficiency analysis has traditionally been approached by means of simple accounting ratios. Currently, however, the use of accounting ratios is being replaced by another type of synthetic indicators (efficiency indicators) which, unlike accounting ratios, insulate from the effects of belonging to one or other business sector, of size, of specialisation, and of the economic environment on costs or profits and, therefore on efficiency $^{2}$. In this way, the performance of firms can be evaluated both in the purely productive sphere (technical efficiency) and on the cost or profit side (cost or profit efficiency) without fearing that the comparison of efficiency among firms will be "contaminated" by the effects of the environment, of market power, or simply by the difference in productive specialisation.

\footnotetext{
${ }^{1}$ See Berg et al. (1993 and 1995), Bergendhal (1995), Fecher and Pestieau (1993), Pastor et al. (1995, 1997a, 1997b and 1999b), Allen and Rai (1996) and Maudos et al. (2000). For an excellent survey about efficiency of the financial institutions see Berger and Humphrey (1997).

2 Thus Maudos et al. (2000) consider specialisation clusters to isolate for the effect of specialisation, Pastor (1999b) and Pastor et al. (1997b) develop techniques that isolate for the effect of environmental variables.
} 
However, in spite of their evident advantages over accounting ratios, these efficiency indicators still offer only a partial view of firms' performance. Indeed, they only assess the achievement, by the firms analysed, of one very specific economic objective: minimisation of costs or maximisation of profits. They do not consider other aspects of banking firms which may be just as important or even more so. In the case of banks one of the most important aspects to be considered is credit risk, because it is desirable not only that a bank should be efficient but also that it should not, in order to obtain lower costs / higher profits, incur excessive problem loans which may endanger the future viability of the firm, or even, depending on the size of the bank, the country's means of payment system. In this sense, some kind of synthetic indicator is necessary to be able to evaluate both efficiency and credit risk simultaneously. We will call this indicator "efficiency adjusted for risk" and obtaining it will be one of the aims of this study.

Although there is a consensus among the experts that a part of the credit risk (measured by problem loans) incurred by banks is due to exogenous causes beyond the firm's control, only Pastor (1999a and b) has decomposed problem loans into its internal and external factors and has included it in the analysis of efficiency by means of a laborious three stage procedure ${ }^{3}$.

The few studies dedicated to obtaining measurements of efficiency adjusted for risk (Hughes and Mester, 1993 and Mester 1994a and b) ignore the consensus in the literature that part of bad loans cannot be attributed to the bank, but to its economic environment. More specifically, in these studies the "adjustment" for risk is done by directly including bad loans as an additional input in the estimation.

The procedure used in these studies is inappropriate for two reasons. Firstly, the measurement of efficiency obtained will be biased if part of the bad loans is due to factors exogenous to the bank (unfavourable economic situation), and the higher the proportion of bad loans attributable to exogenous factors the greater this bias will be. Secondly, the analysis of efficiency is incomplete because it is done in a context of cost efficiency which does not allow for the effect of the quality of assets and of risk on the prices of assets and deposits and therefore on efficiency ${ }^{4}$. These effects on the prices of assets and deposits can only be captured in a context of profit efficiency.

\footnotetext{
${ }^{3}$ For the case of Spain, Saurina (1998) is the most outstanding study of those that analyse rigorously the determinants of problem loans, including exogenous and endogenous factors, although he does not consider decomposing problem loans into its internal and external factors, nor obtaining measurements of efficiency adjusted for risk.

4 Thus, banks that accept riskier borrowers will obtain higher profitability as the latter agree to pay a higher rate of interest. Depositors will only be willing to place their funds in a high risk bank if they are offered a higher return. The cost side would only capture the price effect on the cost of liabilities, but not on the price of assets.
} 
The aim of this study is to analyse the efficiency and the problem loans of the banks of the most important countries of the Euro area. For this purpose we will use a single stage parametric procedure to solve the problems mentioned above. Specifically, the procedure proposed will enable us to identify whether the conduct towards credit risk of the banks analysed - isolating for the effect of the environment, for market power and for specialisation - is more cautious or, on the contrary, more careless during the period analysed. In other words, we will analyse comparatively the efficiency in risk management of the banking systems of the countries analysed, and its evolution over time. This indicator, which controls for the influence of external factors on problem loans, will offer a more adequate view of banks' behaviour towards credit risk than mere observation of the ratio of problem loans over total assets. Additionally, the procedure will be based on the use of a profit frontier approach in order to capture the price effect on the prices of asset products, though for the purposes of comparison we also calculate the cost efficiency measures.

The rest of the study is structured as follows. The second section is devoted to setting out briefly the relationship between risk and efficiency. The third section develops the methodology proposed in the study, detailing the concept of cost and profit efficiency. The fourth section describes the sample used and the variables selected, the fifth presents the results obtained, and finally the sixth section presents the main conclusions of the study.

\section{THE RELATIONSHIP BETWEEN RISK AND EFFICIENCY}

As noted earlier, the indicators of efficiency assess the achievement of a very specific economic objective: minimisation of costs or maximisation of profits. They are very useful indicators, but may in many cases offer a limited view of the behaviour of firms, by omitting other aspects that may also be relevant. Risk is, in the case of banks, one of these aspects, as it is not only desirable that a bank be efficient but also that it should not incur excessive risks in order to obtain lower costs / higher profits ${ }^{5}$.

Some studies have attempted to consider both aspects jointly ${ }^{6}$. They all take into account the close relationship between risk and efficiency. Thus, some studies have found a

\footnotetext{
5 Toevs and Zizka (1994) affirm that the standard ratios normally used by the analysts do not consider risk. Furthermore, they say that to aim to improve efficiency may in some cases be counter-productive, as banks may move their activity into riskier segments of business, with low operating costs and high returns, but assuming a high risk.

${ }^{6}$ See, for example, Hughes Mester (1993), Mester (1994a and b) and Pastor (1999a and b).
} 
negative relationship between cost efficiency and bad loans in bankrupt banks ${ }^{7}$. Berger and De Young (1997) offer several reasons to explain this negative relationship between efficiency and bad loans. Firstly, inefficient banks, as well as having difficulties in the management of costs and revenue, may also be defective managers of risk, in the sense that they make a defective assessment of the implicit risk of each borrower, which would explain why bad management (inefficiency) is usually accompanied by poor risk management and therefore by bad loans. Berger and De Young (1997) call this origin of bad loans "bad management".

Bad loans may additionally be associated with adverse economic circumstances, whether cyclical or structural ${ }^{8}$. Regarding cyclical circumstances, the close relationship between aggregate bad loans and the rate of growth of GDP has been amply demonstrated. As to the structural causes, there is ample evidence that the banks that carry out their activity in more depressed regions or countries present higher rates of bad loans. If this is so, the banks subjected to these circumstances will have to devote additional resources to recovering the bad loans, and we would therefore observe a negative relationship between bad loans and efficiency ${ }^{9}$.

\subsection{The concepts of cost efficiency and profit efficiency}

The concepts of cost and profit efficiency correspond to two specific micro-economic objectives: minimisation of costs and maximisation of profits. The indicator of efficiency aims to measure the degree of achievement of these objectives by comparing the observed costs and profits of each firm with the optimum figures (potential minimum costs or potential maximum profits) that it could have obtained. These optima are calculated by first estimating the cost frontier and the profit frontier. Thus, a cost efficiency value of CE implies that it would be possible to produce the same vector of outputs with a cost saving of (1-CE)·100 per cent. Likewise a profit efficiency indicator of PE implies that the firm has (1-PE) 100 per cent less profits than it could obtain. Efficiency indicators are within the interval $(0,1]$ and equal unity if the bank analysed is one of those that define the best practice observed in the sample, whether in terms of cost or in terms of profits.

\footnotetext{
7 Failed banks tend to be more cost inefficient. See Berger and Humphrey (1992), Barr and Siems (1994), Wheelock and Wilson (1995) and Becher, De Young and Lutton (1995).

${ }^{8}$ Berger and De Young (1997) call this origin of bad debt "bad luck".

9 There could also be a positive relationship between bad loans and efficiency in the event that the banks prefer to devote few resources to the analysis of credit risk. If this is so, in the short term these banks could appear efficient and we would find a positive relationship between efficiency and bad loans.
} 
To illustrate the calculation of efficiency indicators, let us suppose that the production costs of an output vector (y) for banks depends on the vector of input prices (w), on the level of cost inefficiency $(\mathrm{u})$ and on a set of random factors $(\mathrm{v})$ that incorporate the effect of errors of measurement of the variables, good or bad luck, etc. In this case, the cost function can be expressed as:

$\mathrm{C}=\mathrm{C}(\mathrm{y}, \mathrm{w}, \mathrm{u}, \mathrm{v})$

in logarithmic terms and assuming that the efficiency and the random term are mutiplicatively separable from the remaining arguments of the function,

$\ln C=\mathrm{f}(\mathrm{y}, \mathrm{w})+\ln \mathrm{u}+\ln \mathrm{v}$

Once a functional form has been specified for the frontier $f(y, w)$, the standard cost efficiency $(\mathrm{CE})$ is defined as the ratio between the minimum costs $\left(\mathrm{C}^{\mathrm{min}}\right)$ that would permit the output vector $(y)$ to be produced if its cost inefficiency were eliminated $(u=1$ or $\ln u=0)$ given the prices of the inputs $(\mathrm{w})$ and their observed costs,

$\mathrm{CE}=\frac{\mathrm{C}^{\min }}{\mathrm{C}}=\frac{\exp [\mathrm{f}(\mathrm{y}, \mathrm{w})] \exp (\ln \mathrm{v})}{\exp [\mathrm{f}(\mathrm{y}, \mathrm{w})] \exp (\ln \mathrm{u}) \exp (\ln \mathrm{v})}=\exp (-\ln \mathrm{u})$

Profit efficiency (PE) is a broader concept than the traditional cost efficiency indicator (CE) as it takes into account the effect of the choice of a particular vector of outputs, and of the firm's risk policy on both costs and revenue. This is precisely the reason why this concept is more adequate for the objectives of this study.

We can distinguish two profit functions, according to whether or not they consider the existence of market power in the fixing of output prices: the standard and alternative profit functions. The standard profit function assumes perfect competition in the markets for outputs and inputs. With given vectors of output prices (p) and input prices (w), the bank tries to maximise profits by adjusting the vectors of outputs and inputs. Thus, the profits of a bank are a function of a vector of output prices (p), a vector of input prices (w), a set of random factors (v) and profit inefficiency (u),

$\Pi=\Pi(\mathrm{w}, \mathrm{p}, \mathrm{v}, \mathrm{u})$ 
in logarithmic terms and assuming that efficiency and the error term are mutiplicatively separable from the remaining arguments of the profit function,

$$
\ln (\Pi)=f(w, p)+\ln v-\ln u
$$

Standard profit efficiency (PE) is defined as the ratio between the observed profits ( $\Pi$ ) and the maximum profits $\left(\Pi^{\max }\right)$ that the banks could obtain if they eliminated their profit inefficiency $(\mathrm{u}=1$ or $\ln u=0)$ with given prices of inputs $(w)$ and outputs $(p)$,

$$
\mathrm{PE}=\frac{\Pi}{\Pi^{\max }}=\frac{\exp [\Pi(\mathrm{w}, \mathrm{p})] \exp (\ln \mathrm{v}) \exp (-\ln \mathrm{u})}{\exp [\Pi(\mathrm{w}, \mathrm{p})] \exp (\ln \mathrm{v})}=\exp (-\ln \mathrm{u})
$$

The exogenous nature of the price of the vector of production (p) in the above concept of profit efficiency presents the difficulty that it implies assuming the absence of market power in pricing by banks. If instead of taking this price vector as given - i.e. we assume imperfect competition or market power in pricing - we take as given the output vector (y), we have the alternative profit function.

$$
\Pi_{\mathrm{a}}=\Pi_{\mathrm{a}}(\mathrm{y}, \mathrm{w}, \mathrm{v}, \mathrm{u})
$$

This expression is the same as for the traditional cost function except that profits instead of costs are the dependent variable. Observe that in the alternative profit function firms take as given the quantity of output (y) and the price of inputs (w) and maximise profits by adjusting the price of the output ( $p$ ) and the quantity of inputs. As indicated by Berger and Mester (1997), alternative profit efficiency is a closer portrayal of reality whenever the assumption of perfect competition in the setting of prices is questionable, or when there are differences of quality and/or specialisation among the banks forming the sample.

The problem with the estimation of standard profit efficiency is that it requires prior information on the price of each component of the vector of output, information which is not available in the statistical source used in this study. For this reason, as well as for those indicated in the above paragraph (the existence of market power is admitted, as well as different qualities and specialisation of the output vector), in this study we estimate alternative profit efficiency. However, insofar as the sample covers such a diverse group of countries with different levels of competition, the concept of alternative profit efficiency is more appropriate than the concept of standard profit efficiency. 


\subsection{Estimation of efficiency}

The main problem with the measurement of efficiency is to separate genuinely inefficient behaviour from those random factors that affect firms' profits. In the case of the banking sector, the four most commonly used techniques differ from each other in different assumptions they make. Thus, the stochastic frontier approach (SFA) assumes that the observed profits of a bank can deviate from the maximum profits defined by the frontier because of inefficiency or because of random factors, and proposes sophisticated econometric techniques for carrying out the separation. The thick frontier technique (TFA) developed by Berger and Humphrey (1991) proposes a much simpler separation, assuming that the differences among the predicted profits in the upper quartile of profits are due to random factors, whereas the differences in profits among quartiles are due to inefficiency. The data envelopment analysis (DEA) is a determinist technique, and therefore does not make the separation, assuming that any deviation of observed profits from the maximum is due exclusively to inefficiency. Finally, the distribution free approach (DFA) developed by Berger et al. (1993) is based on the hypothesis that inefficiencies persist over time, while the random terms tend to cancel each other out in the course of time.

The availability of a panel of data allows either the fixed effects model (FEM) or the random effects model (REM) to be used. These are based on the idea that efficiency is constant over time, and they present the advantage of not requiring any distributional assumption regarding the inefficiency term ${ }^{10}$.

In the case of FEM the inefficiency term is treated as a constant, specific to each firm. The model is then estimated by OLS. The assumption that the bank with least individual effect (greatest in the case of cost efficiency) is the most efficient of the sample enables the indicators of cost efficiency to be calculated by means of the gap between the individual effect estimated for each bank $\left(\hat{\alpha}_{i}\right)$ and the individual effect for the most cost efficient bank $\left(\hat{\alpha}_{i}^{\min }\right)$ :

$\mathrm{CE}_{\mathrm{i}}=\exp \left(\hat{\alpha}_{\mathrm{i}}^{\min }-\hat{\alpha}_{\mathrm{i}}\right)$

In the case of profit efficiency the efficiency indicators are obtained by means of the gap between the individual effect for the most profit efficient bank $\left(\hat{\alpha}_{i}^{\max }\right)$ and the individual effect estimated for each bank $\left(\hat{\alpha}_{i}\right)$ :

\footnotetext{
${ }^{10}$ For details of these panel techniques and their empirical comparison see Berger and Mester (1997) and Maudos et al. (2000).
} 


$$
P E_{i}=\exp \left(\hat{\alpha}_{i}-\hat{\alpha}_{i}^{\max }\right)
$$

The REM model, on the contrary, takes into account the stochastic nature of efficiency (Simar, 1992), but the estimators it provides are not consistent if the regessors are correlated with the individual effects. In this model the inefficiency term forms part of the random term and is captured by taking the average of the residuals of each firm throughout the period,

$\ln \hat{\varepsilon}_{\mathrm{i}}=\frac{1}{\mathrm{~T}} \sum_{\mathrm{t}=1}^{\mathrm{T}} \ln \hat{\varepsilon}_{\mathrm{it}}$

The indicators of cost efficiency (CE) and profit efficiency (PE) are then computed as follows:

[11] $\quad \mathrm{CE}_{\mathrm{i}}=\exp \left(\varepsilon_{\mathrm{i} \bullet}^{\min }-\varepsilon_{\mathrm{i} \bullet}\right)$

[12] $\quad \mathrm{PE}_{\mathrm{i}}=\exp \left(\varepsilon_{\mathrm{i} \bullet}^{\min }-\varepsilon_{\mathrm{i} \bullet}\right)$

where $\varepsilon_{\mathrm{i} \cdot}$ is the average of the residuals from the cost function in expression [11] and the average of the residuals from the profit function in expression [12].

The DFA technique developed by Berger et al. (1993) is a variant of REM. The only difference is that in DFA the regression coefficients are allowed to vary from year to year to reflect changes in technology and the environment. In DFA the efficiency level of each bank is assumed to be constant over time while the random components cancel each other out. In this way a cost or profit equation is estimated for each year and the efficiency of each firm is computed as the average of the residues of each individual throughout the period. However, since the extreme values may reflect aspects other than efficiency, Berger et al. (1993) recommend that different truncations should be made so that extreme values can be assigned the value corresponding to the point of sample truncation established.

\subsection{Estimation of efficiency adjusted for risk and risk management efficiency}

The main aim of this study is to obtain measurements of efficiency adjusted for risk, so the models expressed in equations [2] and [5] must be completed by filtering for the effect of credit risk. The earlier studies by Hughes and Mester (1993) and Mester (1994a and b) made this correction by including total bad loans as an additional variable in the cost equation. However, as argued above, part of these bad loans is attributable to exogenous 
factors beyond the control of the bank, which should therefore not be considered as otherwise firms subject to adverse environments will be inappropriately penalised. Only Pastor (1998, 1999a and b) considered this possibility and developed a non-parametric model taking this into account and obtained indicators of risk management efficiency (RME)and decomposed one of the main indicators of credit risk (provisions for loan losses) into its exogenous and endogenous factors. However, the three stage technique used is very laborious and suffers the problems associated with the use of deterministic techniques. In this section we propose a single stage parametric technique for estimating jointly the profit (and cost) efficiency adjusted for risk, and the efficiency of risk management.

The model proposed for calculating measurements of efficiency adjusted for risk can be expressed as follows:

$$
\begin{aligned}
& \ln \Pi_{\mathrm{it}}=\mathrm{f}\left(\mathrm{w}_{\mathrm{it}}, \mathrm{y}_{\mathrm{it}}\right)+\gamma \beta \mathrm{X}_{\mathrm{it}}^{\mathrm{INT}}+\rho \mathrm{X}_{\mathrm{kt}}^{\mathrm{ENV}}+\varepsilon_{\mathrm{it}} \\
& \mathrm{M}_{\mathrm{it}}=\delta \mathrm{X}_{\mathrm{it}}^{\mathrm{EXT}}+\beta \mathrm{X}_{\mathrm{it}}^{\mathrm{INT}}+\omega_{\mathrm{it}}
\end{aligned}
$$

where it is assumed that the firm maximises profits $(\Pi)$ by adjusting the quantity of input, given the prices of inputs (w) and given the vector of environmental variables $\mathrm{X}_{\mathrm{k}}^{\mathrm{ENV}}$ inherent to each of the $\mathrm{k}$ banking systems. In equation [14], $\mathrm{M}$ is the indicator of credit risk (i.e. bad loans) $\beta \mathrm{X}_{\mathrm{i}}^{\mathrm{INT}}$ is the estimated part of the bad loans that is attributable to internal factors, and $\delta \mathrm{X}_{\mathrm{i}}^{\mathrm{EXT}}$ is the estimated part attributable to external factors ${ }^{11}$. In the case of cost efficiency adjusted for risk, profits are replaced by costs as the dependent variable of equation [13], i.e. $\mathrm{C}_{\mathrm{it}}$ is substituted for $\Pi_{\mathrm{it}}$.

The indicators of cost and profit efficiency adjusted for risk $\left(\mathrm{CE}_{\mathrm{i}}{ }^{*}\right.$ and $\left.\mathrm{PE}_{\mathrm{i}}{ }^{*}\right)$ for each firm are obtained from expressions [11] and [12]. The traditional unadjusted indicators of cost efficiency $\left(\mathrm{CE}_{\mathrm{i}}\right)$ and profit efficiency $\left(\mathrm{PE}_{\mathrm{i}}\right)$ are obtained by single-equation estimation of a variant of expression [13] which includes no adjustment for risk: $\beta \mathrm{X}_{\mathrm{i}}^{\mathrm{INT}}$.

Likewise, risk management efficiency $\left(\mathrm{RME}_{\mathrm{i}}\right)$ is obtained as the ratio between the minimum bad loans $\left[\overline{\mathrm{M}}_{\mathrm{i} \bullet}+\left(\hat{\omega}_{\mathrm{i} \bullet}^{\min }-\hat{\omega}_{\mathrm{i}} \bullet \overline{\mathrm{A}}_{\mathrm{i} \bullet}\right]\right.$ and observed bad loans $\left(\overline{\mathrm{M}}_{\mathrm{i} \bullet}\right)$ :

\footnotetext{
11 Both profits $\left(\Pi_{\mathrm{it}}\right)$ and bad loans $\left(\mathrm{M}_{\mathrm{it}}\right)$ are expressed in relation to assets. Berger and Mester (1997) advise this transformation for three reasons: 1) problems of heteroskedasticity are reduced; 2) the bias associated with scale is reduced; and 3) the dependent variable is directly the return on assets (ROA) and the ratio of bad loans, so the economic interpretation is more direct. Maudos et al. (2000) also make this transformation.
} 
$\mathrm{RME}_{\mathrm{i}}=\frac{\overline{\mathrm{M}}_{\mathrm{i} \bullet}+\left(\omega_{\mathrm{i} \bullet}^{\min }-\omega_{\mathrm{i} \bullet}\right) \overline{\mathrm{A}}_{\mathrm{i} \bullet}}{\overline{\mathrm{M}}_{\mathrm{i} \bullet}}$

where $\hat{\omega}_{\mathrm{i}}$. are the average residual per firm obtained from expression [14] for the period:

$\hat{\omega}_{\mathrm{i} \bullet}=\frac{1}{\mathrm{~T}} \sum_{\mathrm{t}=1}^{\mathrm{T}} \hat{\omega}_{\mathrm{it}}$

while $\overline{\mathrm{M}}_{\mathrm{i}}$, and $\overline{\mathrm{A}}_{\mathrm{i}}$. are average bad loans and the average assets per individual for the whole period:

$$
\mathrm{M}_{\mathrm{i} \bullet}=\frac{1}{\mathrm{~T}} \sum_{\mathrm{t}=1}^{\mathrm{T}} \mathrm{M}_{\mathrm{it}} ; \quad \overline{\mathrm{A}}_{\mathrm{i} \bullet}=\frac{1}{\mathrm{~T}} \sum_{\mathrm{t}=1}^{\mathrm{T}} \mathrm{A}_{\mathrm{it}}
$$

Among the internal factors $\left(\mathrm{X}^{\mathrm{INT}}\right)$ will be included variables such as the importance of loans in firms' balance sheets or the ratio of financial revenue to total earning assets. Among external factors $\left(\mathrm{X}^{\mathrm{EXT}}\right)$ will be included cyclical variables that capture the different phases of the economic cycle and the different volatility of economies (per capita GDP, GDP growth rate, investment growth rate, inflation, interest rates, unemployment rates, etc.). Additionally, the number of automated teller machines (ATMs) per branch, the number of branches per bank, number of ATMs per inhabitant and per square kilometre, etc., will be considered as differential structural or environmental variables of each country $\left(\mathrm{X}^{\mathrm{ENV}}\right)$. Also, since the aim is to estimate jointly efficiency (in both costs and profits) and the determinants of bad loans, a system of equations will be estimated by the SURE technique.

\section{DATA AND VARIABLES}

All the information on the balance sheet and the profit and loss account of each bank was taken from the international data base IBCA. Extraction of the data revealed the nonexistence of information on one of the most important variables for this study, i.e. bad loans. The lack of information on this variable has been made up for by authors in a variety of ways. Thus for example Saurina (1998) resorts to the annual reports of each bank to analyse the bad loans of the Spanish savings banks. Pastor (1999a and b) uses the variable provision for loans losses (PLL) as a proxy for bad loans, on the assumption that the greater the volume of bad 
loans, the greater the corresponding provision will be. Since in the international context the first possibility is ruled out, in this study, as in Pastor (1999a and b), we use provision for loans losses as the indicator of credit risk ${ }^{12}$.

The sample was selected according to three fundamental criteria: 1) banks belonging to countries of the Euro area; 2) banks whose size was large enough to be able to penetrate foreign markets ${ }^{13}$; and 3 ) banks for which information was available on all the relevant variables for the whole period of analysis (1993-97).

The sample obtained (3620 observations) was subsequently filtered to exclude those banks whose variables were significantly different from the average ${ }^{14}$. The sample finally obtained consists of 2980 observations from seven countries of the Euro area (596 banks). The high representativity of the sample used in comparison with the data from alternative sources such as Bank Profitability (OECD) is shown in table 1.

The first problem faced by all studies that analyse efficiency in banking firms is the identification and measurement of output. This study adopts the value added approach of Berger and Humphrey (1992), considering deposits as inputs and outputs simultaneously. This approach to the problem of identification and measurement of banking output falls broadly within the framework of the "intermediation approach". Under this perspective, and conditioned by the disaggregation of the balance sheet and profit and loss account provided by IBCA, the outputs used are: $y_{1}=$ Loans, $y_{2}=$ Other earnings assets, $y_{3}=$ Deposits (Customer and short term funding). Input prices are defined as follows: $w_{1}=$ Price of deposits (obtained by dividing financial costs by the liability components that generate financial costs), $w_{2}=$ Price of labour (calculated by dividing personnel costs by the number of workers), and $w_{3}=$ Price of physical capital (defined as the ratio of equipment costs divided by the accounting value of physical capital). The descriptive statistics of all these variables are presented in table 2 .

\footnotetext{
${ }^{12}$ The use of the provisions variable could bias the results if the banks use their provisions to "smooth out" their profits, setting aside more when profits are high. This possibility was tested and not rejected by Saurina (1999) for the case of Spanish savings banks.

${ }^{13}$ For this purpose we selected banks with total assets of more than USD 1 billion.

${ }^{14}$ Specifically we eliminated banks with input prices outside the interval defined by $\left(\mu_{\mathrm{w}} \pm \sigma_{\mathrm{w}}\right), \mu_{\mathrm{w}}$ being the mean of the price $w$ and $\sigma_{\mathrm{w}}$ its standard deviation.
} 
Table 1: Significance of the European banking system in the sample (1997) ${ }^{(1)}$

\begin{tabular}{lcrrrr}
\hline & $\begin{array}{c}\mathbf{( 1 )} \\
\text { Total Asset } \\
\mathbf{( O C D E )}^{\mathbf{( 2 )}}\end{array}$ & $\begin{array}{c}\mathbf{( 2 )} \\
\text { \% over EU-7 }\end{array}$ & $\begin{array}{c}\text { (3) } \\
\text { Sample Asset }\end{array}$ & $\begin{array}{c}\text { (4)=(3)/ (1) } \\
\text { \% Asset } \\
\text { included }\end{array}$ & $\begin{array}{c}\text { (5) } \\
\text { Number of } \\
\text { firms }\end{array}$ \\
\hline Gemmany & $4,329,290,657$ & 35.4 & $4,052,594,730$ & 93.6 & 306 \\
Belgium & $838,348,269$ & 6.9 & $572,522,391$ & 68.3 & 18 \\
Spain & $892,086,822$ & 7.3 & $765,861,480$ & 85.9 & 68 \\
France & $3,803,157,273$ & 31.1 & $1,510,171,830$ & 39.7 & 77 \\
Italy & $1,560,807,938$ & 12.8 & $1,023,873,469$ & 65.6 & 78 \\
Luxembourg & $567,989,210$ & 4.7 & $321,510,344$ & 56.6 & 40 \\
Portugal & $221,579,266$ & 1.8 & $103,170,049$ & 46.6 & 9 \\
\hline EU-7 & $\mathbf{1 2 , 2 1 3 , 2 5 9 , 4 3 5}$ & $\mathbf{1 0 0}$ & $\mathbf{8 , 3 4 9 , 7 0 4 , 2 9 3}$ & $\mathbf{6 8 . 3}$ & $\mathbf{5 9 6}$ \\
\hline
\end{tabular}

(1) Millions of \$US.

(2) Bank Profitability (OCDE).

(3) IBCA.

Source: IBCA Ltd. and Bank Profitabililty (OCDE).

Table 2: Descriptive statistics of the variables: $1993-1997^{(1)}$

\begin{tabular}{lrrrr}
\hline & Average & Coef. Var. & Max & Min \\
\hline P=0perating profit & 113,679 & 2.10 & $3,691,979$ & 227 \\
A=T otal assets & $13,464,713$ & 2.50 & $419,892,287$ & $1,000,291$ \\
$\mathbf{y}_{\mathbf{1}}=$ Loans & $6,417,865$ & 2.60 & $215,615,666$ & 2,106 \\
$\mathbf{y}_{\mathbf{2}}=$ O ther eaming assets & $6,375,285$ & 2.64 & $198,162,543$ & 113 \\
$\mathbf{y}_{\mathbf{3}}=$ Deposits & $9,833,187$ & 2.57 & $382,935,165$ & 4,212 \\
$\mathbf{w}_{\mathbf{1}}=$ Price of loanable funds & 0.055 & 0.320 & 0.123 & 0.018 \\
$\mathbf{w}_{\mathbf{2}}=$ Price of labor & 0.012 & 0.500 & 0.026 & 0.007 \\
$\mathbf{w}_{\mathbf{3}}=$ Price of physical capital & 0.958 & 1.060 & 9.077 & 0.019 \\
\hline (1) P, A, $\mathrm{y}_{1}, \mathrm{y}_{2}, \mathrm{y}_{3}$ in millions of \$US. & & & &
\end{tabular}

Source: IBCA Ltd. 
The economic cycle variables $\left(\mathrm{X}^{\mathrm{EXT}}\right)$ initially considered to influence bad loans appear in table 3. A priori, a higher rate of growth of GDP in real terms, a higher rate of growth of investment, a higher level of per capita income or a higher rate of inflation ${ }^{15}$ could be expected to have a negative effect on bad debt. On the other hand a higher rate of unemployment and/or higher interest rates would be expected to have a positive effect on bad debt. It can be observed that, for example, the banks that operate in Luxembourg enjoy a favourable economic situation in the sense that the economy of Luxembourg throughout this period was characterised by high rates of growth of GDP and investment, high levels of per capita income, low interest rates and low rates of unemployment. However, the banks of countries like Spain or Portugal operate in much more unfavourable situations (in cyclical terms). It is therefore clearly necessary to filter for environmental influence in order not to attribute to inefficiency of risk management the effects of an unfavourable situation.

Furthermore, there are structural or environmental variables $\left(\mathrm{X}^{\mathrm{ENV}}\right)$ which may influence the everyday conditions in which the banks carry out their activity and which have to be considered. Numerous studies have found that the traditional relative inefficiency of the Spanish banking system compared to other countries is not so, but can be explained by the different specialisation of Spanish banks, by the different density of demand, by their retail orientation, etc. ${ }^{16}$

In this sense the environmental variables initially considered appear in the second part of table 3. Initially we considered the number of ATMs per branch, the number of branches per bank, the number of ATMs per inhabitant and per square kilometre, the number of transactions in ATMs per inhabitant and assets per branch. These variables aim to capture the degree of performance of services achieved by each of these banking systems. It is to be expected that with a greater number of ATMs per branch, per inhabitant and per square kilometre, greater numbers of branches per bank and of transactions in ATMs per inhabitant, and less assets per branch, the degree of performance of services demanded of the banking system considered will be higher, and in this sense the banks operating in it will ceteris paribus bear higher operating costs than those operating in other banking systems where such a level of performance of services is not demanded. For this reason the influence of these variables on cost efficiency will be negative. However, to the extent that this higher level of services is explicitly charged for by the banks, we will be unable to verify its influence on profit efficiency, because if the commissions charged for the performance of these services more than offset the associated costs, their influence will be positive, otherwise negative.

\footnotetext{
15 At aggregate level, it has been found that higher rates of inflation favour debtors, whose debts are reduced in real terms.

${ }^{16}$ See Maudos et al. (2000) and Pastor et al. (1995).
} 
Table 3: Environmental variables: business cycle and structural variables (average 1993-97)

\begin{tabular}{|c|c|c|c|c|c|c|c|}
\hline & Germany & Belgium & Spain & France & Italy & Luxemb. & Portugal \\
\hline \multicolumn{8}{|l|}{$\underline{\mathrm{X}^{\mathrm{EXT}}=\text { Business cycle: }}$} \\
\hline GDP rate of growth ${ }^{(1)}$ & 1.2 & 1.5 & 1.9 & 1.5 & 1.2 & 4.7 & 2.2 \\
\hline GDP per capita ${ }^{(1)}$ & 19.239 & 18.959 & 12.908 & 19.672 & 18.387 & 29.231 & 9.037 \\
\hline Investment rate of growth. & -0.6 & 1.3 & 1.3 & -0.7 & -0.8 & 4.7 & 3.8 \\
\hline Inflation rate ${ }^{(2)}$ & 2.5 & 2.1 & 3.9 & 1.7 & 3.9 & 2.1 & 4.2 \\
\hline Short term interest rate ${ }^{(3)}$ & 4.7 & 5.0 & 8.4 & 5.5 & 8.9 & 5.0 & 9.2 \\
\hline Long term interest rate ${ }^{(4)}$ & 6.2 & 6.9 & 9.3 & 6.7 & 10.0 & 6.6 & 9.3 \\
\hline Unemployment rate & 8.6 & 12.6 & 22.3 & 12.0 & 11.7 & 2.2 & 6.7 \\
\hline \multicolumn{8}{|l|}{$\underline{X}^{\mathrm{ENV}}=$ Structural variables: } \\
\hline ATMs/Branches & 0.77 & 0.21 & 0.75 & 0.86 & 1.01 & 0.51 & 1.20 \\
\hline Branches/Number of firms & 12.50 & 130.20 & 115.80 & 18.00 & 74.50 & 1.70 & 90.50 \\
\hline ATMs/Population ${ }^{(5)}$ & 414.70 & 371.90 & 695.60 & 391.10 & 367.40 & 454.80 & 432.30 \\
\hline ATMs $/ \mathrm{Km}^{2}$ & 0.09 & 0.12 & 0.05 & 0.04 & 0.07 & 0.07 & 0.05 \\
\hline Transactions/Population & 13.40 & 13.90 & 13.90 & 16.30 & 5.60 & 9.70 & 14.90 \\
\hline Total assets/Branches ${ }^{(6)}$ & 88.50 & 42.40 & 23.90 & 134.80 & 73.10 & 1500.00 & 52.90 \\
\hline \multicolumn{8}{|l|}{ (1) U.S. dollars of 1990.} \\
\hline \multicolumn{8}{|l|}{ (2) Based on CPIs. } \\
\hline \multicolumn{8}{|l|}{ (3) 3-month interbank rates. } \\
\hline \multicolumn{8}{|c|}{ (4) 10-year governmnet debt yields. } \\
\hline \multicolumn{8}{|l|}{ (5) Per million of inhabitants. } \\
\hline 6) Millions of 1990 U.S. dolla & & & & & & & \\
\hline
\end{tabular}

Source: National Accounts (OECD), Banco de España, INE, Labor Force Statistics (OECD), Bank Profitability (OCDE) and Payment Systems in the EU (European Monetary Institute). 
The close correlation between our indicator of credit risk (provision for loan losses PLL) and the economic cycle can be observed in figure 1, which shows PLL over assets (left axis) and the rate of growth of GDP with its sign changed (right axis). In it we observe that the stage that we are considering is a phase of expansion that covers the period immediately after the crisis of 1993. In all cases credit risk seems to decrease, though this does not necessarily mean that the banks are behaving more cautiously or that their risk management has improved. The reason is that the evolution of PLL due to the influence of three factors whose effects have to be separated: economic cycle, behaviour towards risk, and risk management. The next section will address these matters.

\section{RESULTS}

Table 4 shows the average costs per unit of assets and the return on assets of the banks considered for the whole period 1993-97, distinguishing by countries, by institutional/specialisation groups, and by size. The first notable characteristic is the high coefficient of variation, indicative of a high degree of heterogeneity, more so on the profit side than on the cost side. Thus some banking systems with a ROA of $1.317 \%$ (Spain) or $1.229 \%$ (Portugal) coexist with others with lower returns on assets such as France $(0.609 \%)$ and Luxembourg $(0.734 \%)$. On the cost side, the Spanish, Portuguese and Italian banking systems operate with the highest average costs, though as we have seen, in the case of the Spanish and Portuguese banking sectors they are able to more than recover these high average costs through revenue and become at the same time the most profitable banking sectors.

With respect to differences of institutions or of specialisation, savings banks and credit co-operatives are seen to have highest average costs, given their retail specialisation, although they can recover these costs via revenue and be, at the same time, the most profitable institutional groups. The same occurs with the banks of smaller size - they have the highest costs and yet are the most profitable.

These characteristics are also reflected in the low correlation between the rankings in terms of average costs and in terms of profitability. Thus, the correlation among countries in terms of these two variables is only $0.214^{17}$. This result suggests, once again, that having high (low) costs does not necessarily imply achieving low (high) profits, making it necessary to consider the importance of the revenue side when valuing efficiency.

\footnotetext{
${ }^{17}$ Maudos et al. (2000) obtain the same result; correlation 0.43.
} 
Figure 1: Provision for loan losses (PLL) and business cycle ${ }^{(1)}$

Germany

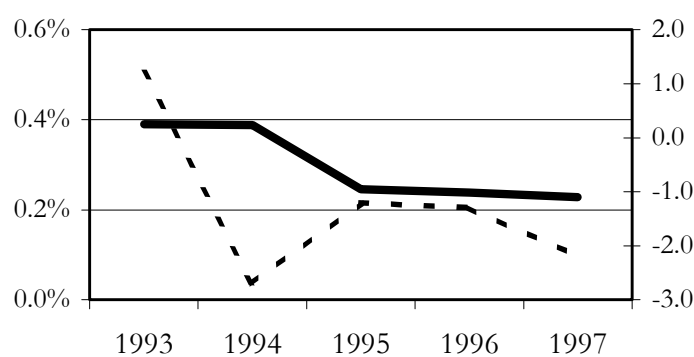

Spain

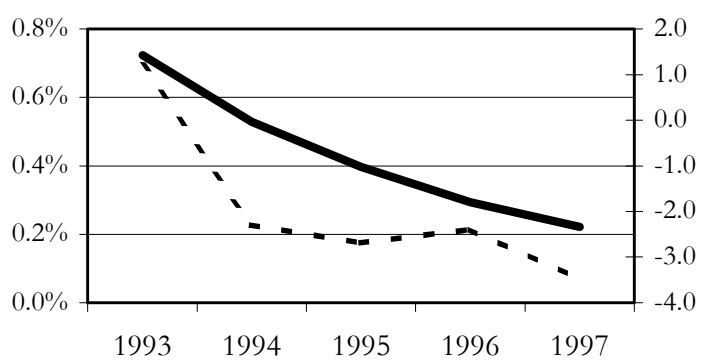

Italy

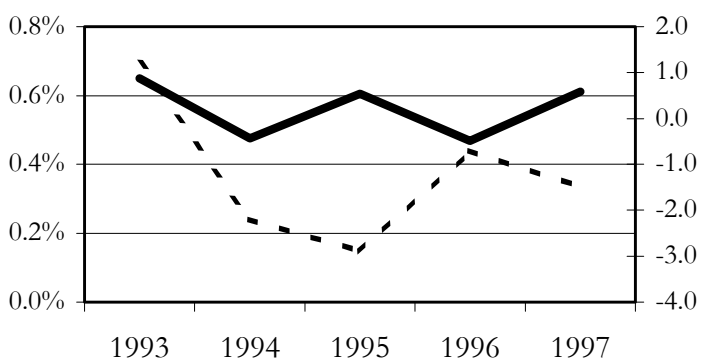

Belgium

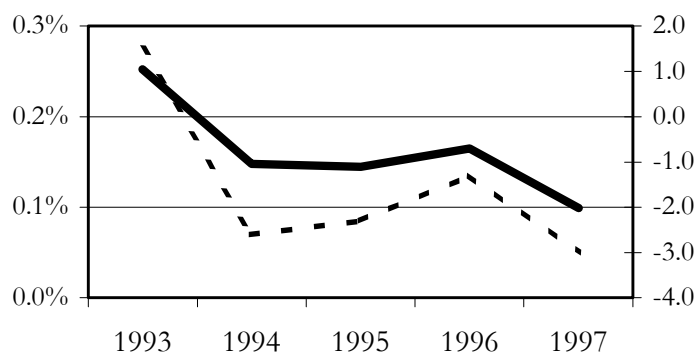

France

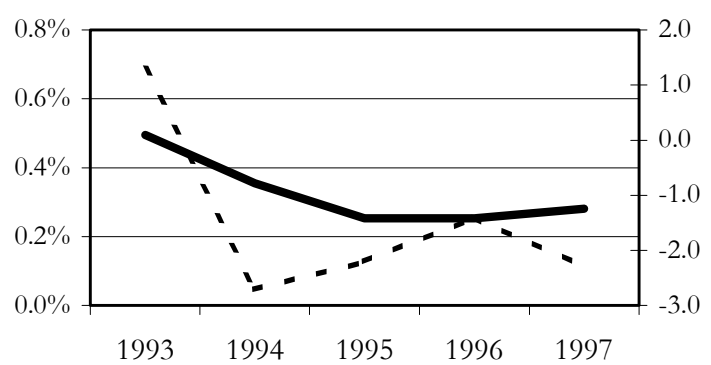

Luxembourg

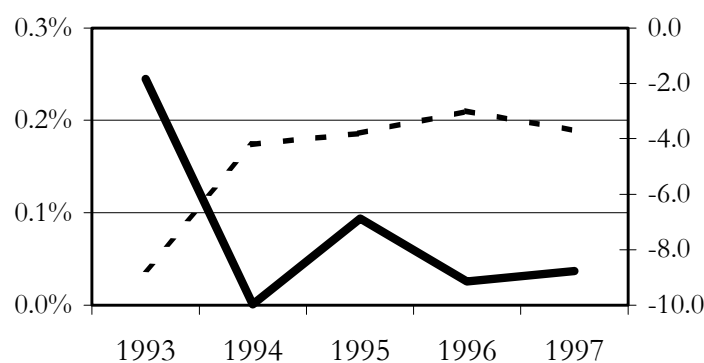

Portugal

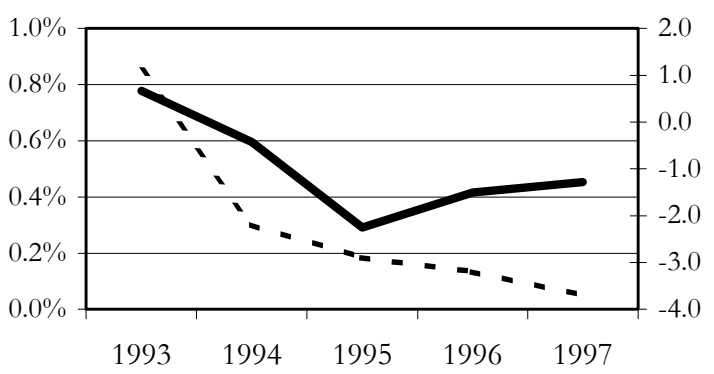

PLL - - - (-) Rate of growth of GDP

Notes:

(1) (-) Rate of growth of GDP. 
Table 4: Total costs and profits over total assets (1993-97)

\begin{tabular}{|c|c|c|}
\hline & CT/A & $\overline{\text { ROA }}$ \\
\hline Gemany & 5.763 & 0.818 \\
\hline Belgium & 6.168 & 0.488 \\
\hline Spain & 7.670 & 1.317 \\
\hline France & 5.966 & 0.609 \\
\hline Italy & 7.956 & 1.111 \\
\hline Luxembourg & 6.445 & 0.734 \\
\hline Portugal & 8.495 & 1.229 \\
\hline Commencial banks & 6.515 & 0.813 \\
\hline Cooperatives & 6.578 & 1.056 \\
\hline Savings banks & 6.629 & 1.305 \\
\hline Mortgage & 5.889 & 0.602 \\
\hline Others $^{(1)}$ & 5.698 & 0.608 \\
\hline Small $^{(2)}$ & 6.742 & 1.421 \\
\hline Large $^{(3)}$ & 6.696 & 1.048 \\
\hline Very lange $^{(4)}$ & 6.107 & 0.659 \\
\hline EU-7 & 6.330 & 0.844 \\
\hline Std. & 0.012 & 0.008 \\
\hline Coef. Var. & 0.002 & 0.009 \\
\hline
\end{tabular}

(1) Includes investment banks and specialized government banks.

(2) Banks with total assets less than 5 billions of U.S. dollars.

(3) Banks with total assets between 5 and 30 billions of U.S dollars.

(4) Banks with total assets over 30 billions of U.S. dollars.

Source: IBCA Ltd. and own preparation. 
Tables 5 and 6 contain the average cost and profit efficiency levels estimated by means of the DFA technique ${ }^{18}$. Each table offers both the estimation of cost efficiency (CE) and profit efficiency (PE), and of the estimation risk-adjusted efficiency measures ( $\mathrm{CE}^{*}$ and $\left.\mathrm{PE}^{*}\right)$. The results are presented for different levels of truncation.

The first notable feature is that the levels of efficiency depend largely on the level of truncation chosen. Thus, for example, the unadjusted average level of cost efficiency rises from 0.555 when it is not truncated, to 0.733 when only $1 \%$ of the extreme values are replaced by the truncation value, and to 0.835 with $5 \%$ truncation, but only increases to 0.894 when truncated at $10 \%{ }^{19}$. The result is very similar to that obtained by Maudos et al. (2000) and suggests that even after using time averages of several years (in our case five), there still remain a high proportion of random factors, other than efficiency, that are not cancelled out in the course of time. This effect is corrected, as in Berger et al. (1993) and Berger and Mester (1997) and Maudos et al. (2000), by replacing the more extreme values with those of the truncation points. This procedure suggests that having reached a certain point, in our case $5 \%$ or $10 \%$, efficiency measurements are not substantially altered.

The results obtained indicate that for the group of countries considered, cost efficiency is $89.4 \%{ }^{20}$, indicating that it would be possible to reduce costs by $10.6 \%$ simply by eliminating allocative and $\mathrm{X}$-inefficiencies. By countries, the results indicate that France and Luxembourg are the most efficient countries, whereas Spain and Portugal are the most inefficient.

The analysis by institutions reveals that commercial banks are the most cost efficient while the savings banks are the least efficient, suggesting that the retail specialisation of the savings banks places them at a disadvantage in terms of cost efficiency. However, the question also arises whether this disadvantage is maintained in terms of profits.

The observation of the results by size of firm also reveals that it is the largest firms that enjoy advantages in terms of cost efficiency. That is to say, there exist other circumstances, apart from economies of scale, that enable large firms to enjoy advantages in cost efficiency.

\footnotetext{
18 The frontier cost and profit function of expression [13] takes the translogarithmic specification, and we imposed the usual restrictions of grade one homogeneity and symmetry in the prices of inputs. The homogeneity restrictions were only imposed on the cost frontier. The DFA technique allows the estimated parameters of the cost and profit function to vary over time the better to capture changes in technology and environment.

${ }^{19}$ Subsequent increases in the percentage of sample truncated do not cause significant changes in the average levels of efficiency.

${ }^{20}$ Maudos et al. (2000) obtain $91.4 \%$ for a sample of 11 countries of the EU.
} 
Table 5: Cost efficiency indicators (CE y CE*)

\begin{tabular}{|c|c|c|c|c|c|c|c|c|}
\hline & \multicolumn{4}{|c|}{ Cost efficiency (CE) } & \multicolumn{4}{|c|}{ Risk-Adjusted cost efficiency (CE $\left.{ }^{*}\right)$} \\
\hline & $0 \%$ & $1 \%$ & $5 \%$ & $10 \%$ & $0 \%$ & $1 \%$ & $5 \%$ & $10 \%$ \\
\hline Germany & 0.552 & 0.730 & 0.832 & 0.897 & 0.640 & 0.770 & 0.840 & 0.890 \\
\hline Belgium & 0.553 & 0.732 & 0.834 & 0.897 & 0.633 & 0.761 & 0.830 & 0.878 \\
\hline Spain & 0.527 & 0.697 & 0.792 & 0.849 & 0.604 & 0.726 & 0.798 & 0.843 \\
\hline France & 0.606 & 0.802 & 0.911 & 0.952 & 0.678 & 0.815 & 0.889 & 0.935 \\
\hline Italy & 0.534 & 0.706 & 0.804 & 0.865 & 0.612 & 0.736 & 0.803 & 0.851 \\
\hline Luxembourg & 0.555 & 0.734 & 0.837 & 0.902 & 0.649 & 0.781 & 0.854 & 0.904 \\
\hline Portugal & 0.488 & 0.646 & 0.738 & 0.801 & 0.602 & 0.724 & 0.792 & 0.840 \\
\hline Commercial banks & 0.569 & 0.752 & 0.856 & 0.914 & 0.646 & 0.777 & 0.849 & 0.897 \\
\hline Cooperatives & 0.552 & 0.731 & 0.832 & 0.893 & 0.642 & 0.773 & 0.843 & 0.891 \\
\hline Savings banks & 0.522 & 0.690 & 0.786 & 0.849 & 0.610 & 0.733 & 0.802 & 0.850 \\
\hline Mortgage & 0.530 & 0.699 & 0.796 & 0.859 & 0.622 & 0.748 & 0.816 & 0.864 \\
\hline Others $^{(1)}$ & 0.550 & 0.727 & 0.828 & 0.887 & 0.636 & 0.765 & 0.836 & 0.883 \\
\hline Small $^{(2)}$ & 0.540 & 0.713 & 0.812 & 0.872 & 0.635 & 0.763 & 0.832 & 0.879 \\
\hline Lange $^{(3)}$ & 0.536 & 0.708 & 0.807 & 0.869 & 0.625 & 0.752 & 0.820 & 0.868 \\
\hline Very large $^{(4)}$ & 0.566 & 0.749 & 0.852 & 0.910 & 0.643 & 0.774 & 0.845 & 0.894 \\
\hline EU-7 & 0.555 & 0.733 & 0.835 & 0.894 & 0.637 & 0.766 & 0.837 & 0.885 \\
\hline Std. & 0.057 & 0.071 & 0.073 & 0.068 & 0.062 & 0.072 & 0.071 & 0.068 \\
\hline Coef. Var. & 0.103 & 0.097 & 0.087 & 0.076 & 0.097 & 0.094 & 0.084 & 0.077 \\
\hline
\end{tabular}

(1) Includes investment banks and specialized government banks.

(2) Banks with total assets less than 5 billions of U.S. dollars.

(3) Banks with total assets between 5 and 30 billions of U.S dollars.

(4) Banks with total assets over 30 billions of U.S. dollars.

Source: IBCA Ltd. and own preparation. 
Table 6: Profit efficiency indicators (PE y PE*)

\begin{tabular}{|c|c|c|c|c|c|c|c|c|}
\hline & \multicolumn{4}{|c|}{ Profit efficiency (PE) } & \multicolumn{4}{|c|}{ Risk-Adjusted profit efficiency (PE $\left.{ }^{*}\right)$} \\
\hline & $0 \%$ & $1 \%$ & $5 \%$ & $10 \%$ & $0 \%$ & $1 \%$ & $5 \%$ & $10 \%$ \\
\hline Germany & 0.256 & 0.381 & 0.492 & 0.544 & 0.302 & 0.368 & 0.497 & 0.570 \\
\hline Belgium & 0.241 & 0.359 & 0.467 & 0.518 & 0.307 & 0.375 & 0.509 & 0.585 \\
\hline Spain & 0.251 & 0.375 & 0.495 & 0.552 & 0.312 & 0.381 & 0.515 & 0.594 \\
\hline France & 0.188 & 0.283 & 0.375 & 0.427 & 0.271 & 0.332 & 0.455 & 0.527 \\
\hline Italy & 0.230 & 0.343 & 0.445 & 0.502 & 0.312 & 0.380 & 0.513 & 0.587 \\
\hline Luxembourg & 0.296 & 0.441 & 0.566 & 0.623 & 0.351 & 0.428 & 0.577 & 0.658 \\
\hline Portugal & 0.274 & 0.410 & 0.531 & 0.587 & 0.240 & 0.293 & 0.396 & 0.460 \\
\hline Commercial banks & 0.221 & 0.329 & 0.428 & 0.480 & 0.294 & 0.358 & 0.485 & 0.556 \\
\hline Cooperatives & 0.278 & 0.416 & 0.546 & 0.608 & 0.339 & 0.415 & 0.565 & 0.648 \\
\hline Savings banks & 0.274 & 0.409 & 0.534 & 0.593 & 0.316 & 0.386 & 0.524 & 0.603 \\
\hline Mortgage & 0.238 & 0.355 & 0.461 & 0.513 & 0.261 & 0.318 & 0.430 & 0.497 \\
\hline others $^{(1)}$ & 0.253 & 0.377 & 0.490 & 0.542 & 0.298 & 0.364 & 0.492 & 0.565 \\
\hline Small $^{(2)}$ & 0.292 & 0.435 & 0.565 & 0.625 & 0.327 & 0.399 & 0.540 & 0.620 \\
\hline Lange $^{(3)}$ & 0.282 & 0.421 & 0.550 & 0.610 & 0.323 & 0.394 & 0.535 & 0.615 \\
\hline Very lange $^{(4)}$ & 0.207 & 0.309 & 0.402 & 0.451 & 0.280 & 0.341 & 0.462 & 0.531 \\
\hline$\overline{E U-7}$ & 0.241 & 0.359 & 0.468 & 0.522 & 0.301 & 0.367 & 0.497 & 0.571 \\
\hline Std. & 0.109 & 0.155 & 0.185 & 0.192 & 0.113 & 0.134 & 0.165 & 0.171 \\
\hline Coef. Var. & 0.452 & 0.431 & 0.395 & 0.368 & 0.377 & 0.364 & 0.331 & 0.299 \\
\hline
\end{tabular}

(1) Includes investment banks and specialized government banks.

(2) Banks with total assets less than 5 billions of U.S. dollars.

(3) Banks with total assets between 5 and 30 billions of U.S dollars.

(4) Banks with total assets over 30 billions of U.S. dollars.

Source: IBCA Ltd. And own preparation. 
However, these indicators of efficiency do not consider banks' behaviour regarding risk. Authors have traditionally included total bad loans as an additional exogenous variable. As explained earlier, this procedure is inadequate, as only the part of bad debt that is due to internal factors should be included to penalise (reward) daring (cautious) firms. This adjustment is achieved by estimating the model represented in equations [13] and [14] in which equation [13] includes the part of bad debt due to internal factors.

The results obtained for cost efficiency adjusted for risk $\left(\mathrm{CE}^{*}\right)$ appear at the right of table 5. As can be seen, the correction hardly influences the results. Neither the efficiency level, nor the rankings by country, by institution or by size, are significantly altered. Indeed, France and Luxembourg continue to be the most efficient countries, and Spain, Italy and Portugal the most inefficient, after adjustment for behaviour towards risk. Likewise, commercial banks are the institutional group with the highest level of efficiency in costs and the savings banks the most inefficient. Finally, the biggest banking firms are the most efficient.

The small difference between the adjusted and unadjusted results for cost efficiency may reflect the small impact of behaviour toward risk on the prices of inputs, and specifically on the price of deposits. As shown by Pastor (1999a) the effects of behaviour towards risk affect the prices of both asset products and liability products. Thus daring banks must pay more to depositors per unit of deposit captured, and this price effect will be captured by the cost function. However, at the same time, the riskiest asset clients (borrowers) will also be willing to pay higher rates of interest. Obviously these price effects on asset and liability prices can only be captured by profit function.

Table 6 presents the estimates obtained for the estimation of profit efficiency, unadjusted for risk (PE) at the left, adjusted for risk $\left(\mathrm{PE}^{*}\right)$ at the right. The first notable feature is that, as occurred with profit efficiency, the efficiency levels, though not their relative position, depend on the point of truncation selected. Once again, for a truncation level of $5 \%$ or $10 \%$ the levels of efficiency hardly alter, so we will concentrate on $10 \%$.

Secondly, the index of profit efficiency is lower than that of cost efficiency, which is indicative of the great importance of the revenue side, not analysed when we concentrate only on the cost side. This result is common to the few studies that compare cost efficiency and profit efficiency. Thus, Berger and Mester (1997) and Rogers (1998) obtain this same result for the case of the U.S. banking system. Maudos et al. (2000) obtain a similar result for the case of 11 European banking systems and, as in this study, profit efficiency levels are much lower than those of cost efficiency. 
The information by countries shows a different range of variation. Indeed, whereas France was the most efficient country in costs, now it is the least efficient in profits. Spain and Portugal, which were the most cost inefficient countries, are now in the group of the most profit efficient countries, with efficiency indices of 55.2\% and 58.7\% respectively. This very interesting result reveals that the retail banking specialisation (high operating costs) of these countries placed them at a disadvantage in terms of cost efficiency; however, this specialisation, though costly, enables them to recover via revenue their higher costs, and consequently from the point of view of profit generation, these banking systems are more efficient in profits than in costs.

The same conclusion can be obtained if we concentrate on the efficiency indices by institutional groups. Whereas from the cost viewpoint the commercial banks, much more wholesale-oriented, were the most efficient banking group and the savings banks the most inefficient, the opposite now occurs. Indeed, the retail specialisations of the savings banks, though more costly, enable them to recover these costs via revenue, and consequently they become the second most efficient group, after the co-operatives, while the commercial banks become the most inefficient group.

The configuration by sizes is also noticeably different. Before, the most efficient group from the cost viewpoint was that of the very large banks, now the most efficient from the profit viewpoint are the small banks, and the big ones the most inefficient. This result in fact captures the institutional characteristic remarked on earlier, as the small banks group includes practically all the credit co-operatives and most of the savings banks, while among the very big banks are many commercial banks.

The right side of table 6 presents the results of the estimation of profit efficiency adjusted for risk $\left(\mathrm{PE}^{*}\right)$. The first notable feature is that whereas adjusting for risk only affected the average measurement of cost efficiency by about $1 \%$ (from 0.894 to 0.885 ), the average risk-adjusted profit efficiency is now about $9 \%$ higher that the unadjusted one $(0.571$ as opposed to 0.522 ), making it clear once again that where behaviour towards risk really matters is from the profit viewpoint.

By countries, it can be observed that most of them do not change their position in the ranking. The only exception is Portugal, which moves from second position in profit efficiency to become the most inefficient country after adjusting for risk. This feature seems to indicate that Portuguese banks carry out much more daring risk policies than those of their EU partners. The adjusted measurements likewise offer different results in respect of institutional and size differences, indicating that adjustment for risk is important in the case of profit efficiency. 
The appendix reports the coefficients obtained from the joint estimation of equations [13] and [14]. It can be seen that in most cases the signs are as expected. Thus, with regard to internal variables $\left(\mathrm{X}^{\mathrm{INT}}\right)$ a higher percentage of credit over assets or revenue over assets has a positive and significant influence on bad debt. Among environmental variables $\left(\mathrm{X}^{\mathrm{ENV}}\right)$, a higher number of ATMs per branch, of branches per firm and of assets per branch have a positive significant influence on profits, indicating that the higher costs deriving from a high level of service are more than offset by the commissions charged, finally influencing profits positively. The expected signs for the external variables $\left(\mathrm{X}^{\mathrm{EXT}}\right)$ indicate that the banks of countries with higher per capita GDP, higher rates of inflation and higher unemployment have significantly less bad loans ${ }^{21}$. On the other hand those countries where real interest rates are higher have higher bad loans, capturing the difficulty of repayment faced by borrowers in an environment of high real interest rates.

Figure 2 presents the evolution over time of the adjusted indices of efficiency, on both cost and profit sides ${ }^{22}$. Several aspects can be highlighted: 1) cost efficiency adjusted for risk $\left(\mathrm{CE}^{*}\right)$ is very stable over the whole period analysed; 2) likewise, profit efficiency adjusted for risk $\left(\mathrm{PE}^{*}\right)$ is very stable, though in most countries a clear improvement can be appreciated; 3 ) in all cases profit efficiency is lower than cost efficiency.

Figure 3 presents the evolution over time of profit efficiency adjusted ( $\left.\mathrm{PE}^{*}\right)$ and unadjusted (PE) for risk. The most notable features are: 1) a general trend for profit efficiency adjusted for risk to increase; 2) unlike the adjusted measures, in some countries a worsening of the unadjusted efficiency measures can be observed, such as in Germany, Spain and Portugal; and 3) in all cases the adjusted measures are higher than the unadjusted ones, this difference being wider in some countries such as Germany and smaller in others such as Portugal.

At this point it is worth analysing whether the profit and cost efficiency indicators, adjusted and unadjusted, meet the requirements of consistency proposed by Bauer et al. (1998). For this purpose we will compare the indicators obtained with well known accounting ratios. Table 7 shows the ranking correlations among unadjusted cost and profit efficiency measurements ( $\mathrm{CE}$ and $\mathrm{PE})$, those adjusted for risk ( $\mathrm{CE}^{*}$ and $\left.\mathrm{PE}^{*}\right)$ and the most frequently used accounting ratios: profits per unit of assets (return on assets - ROA) and total costs per unit of assets (TC/A). The most notable results are:

\footnotetext{
${ }^{21}$ This negative relationship between unemployment and bad debt was also found by Pastor (1998).

22 The use of the DFA technique prevents the calculation of efficiency indices for each year. For this reason, the indices have been calculated as moving average of the residuals of the estimations by triennia.
} 
Figure 2: Profit efficiency (PE $\left.{ }^{*}\right)$ and cost efficiency $\left(\mathrm{CE}^{*}\right)$ adjusted for risk

Germany

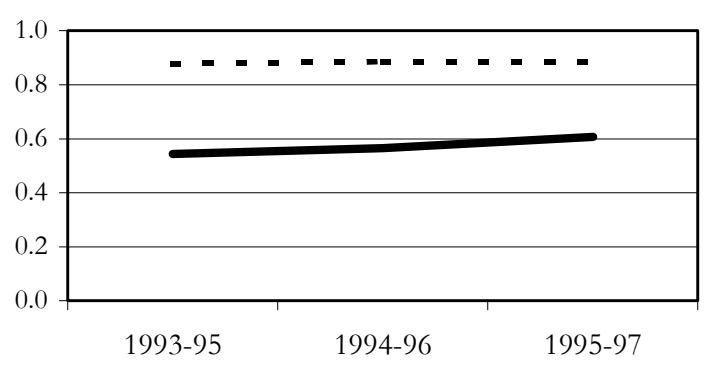

Spain

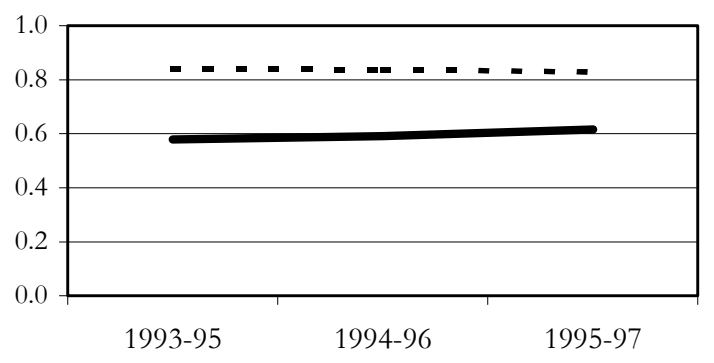

Italy

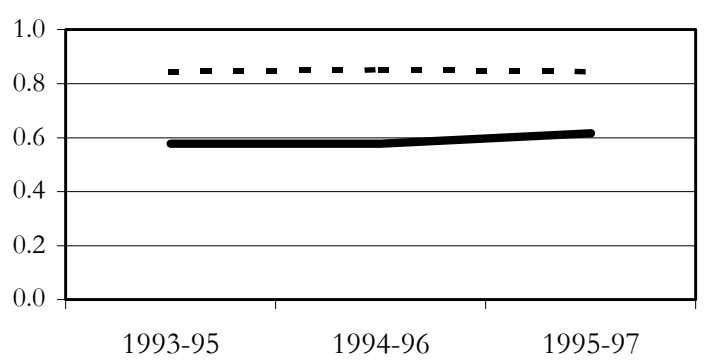

Belgium

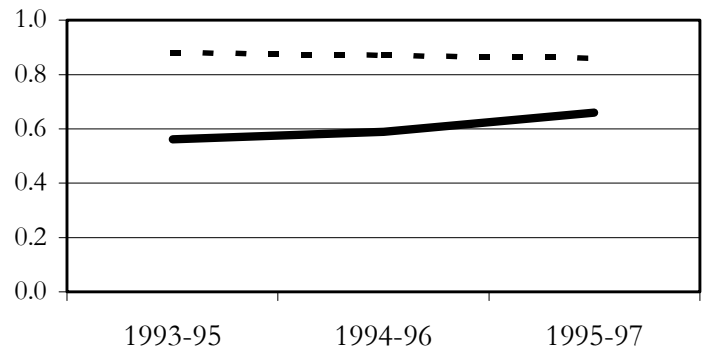

France

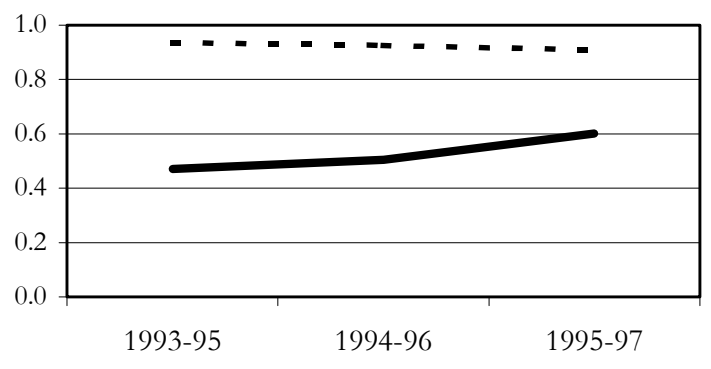

Luxembourg

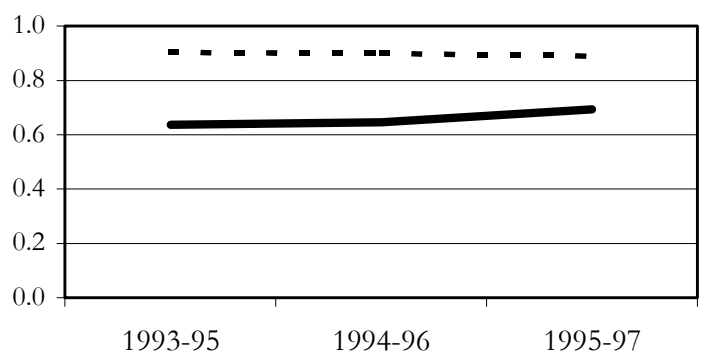

Portugal

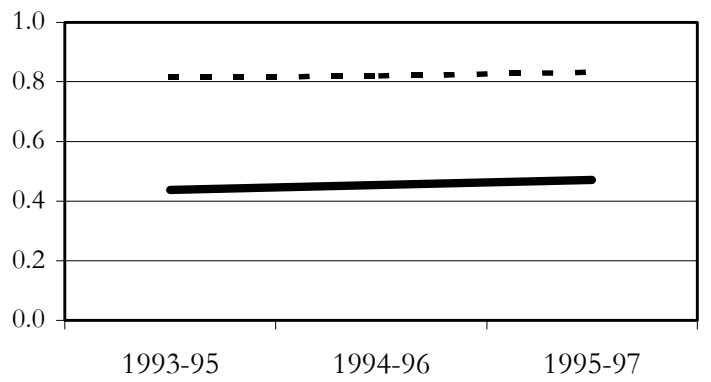

$\mathrm{PE}^{*}$ - - - $\mathrm{CE}^{*}$

Source: IBCA Ltd. and own preparation. 
Figure 3: Profit efficiency (PE) and risk-adjusted profit efficiency (PE $\left.{ }^{*}\right)$

Germany

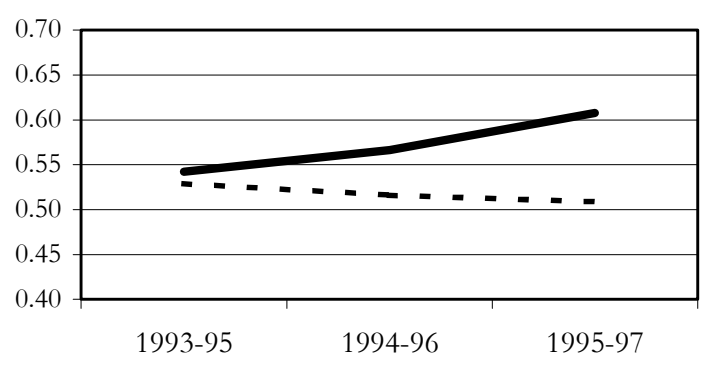

Spain

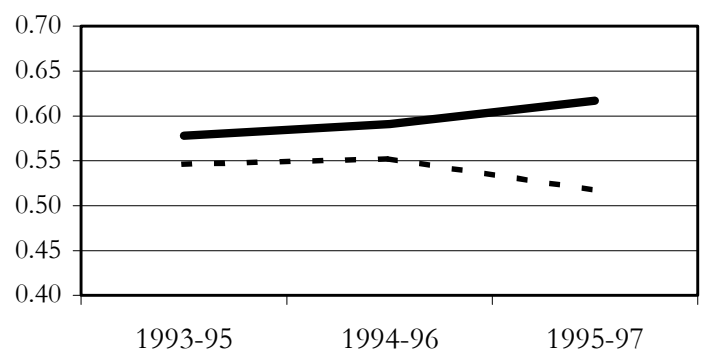

Italy

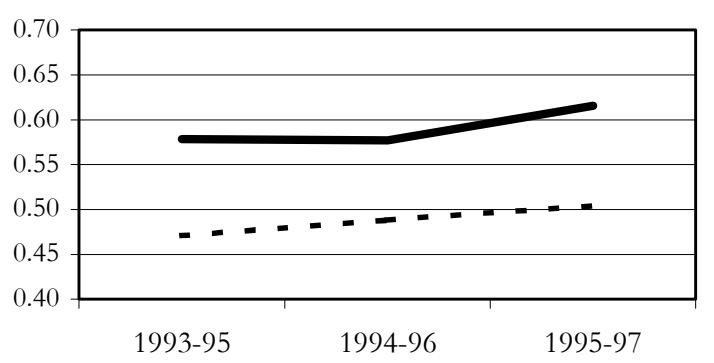

Belgium

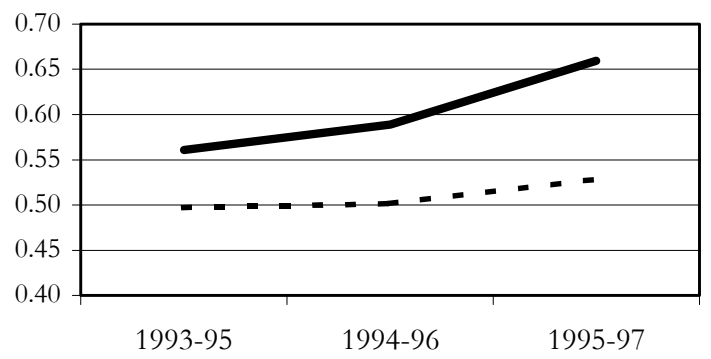

France

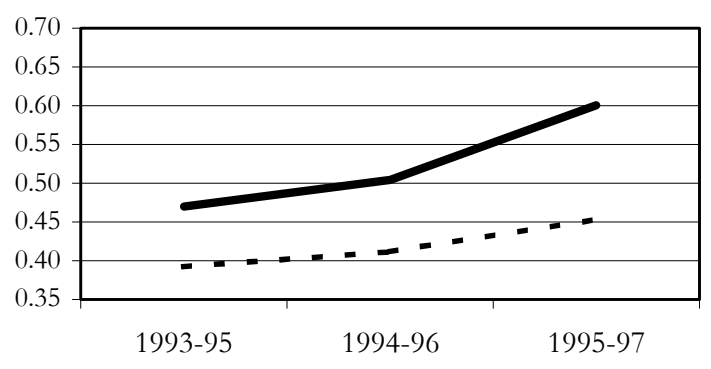

Luxembourg

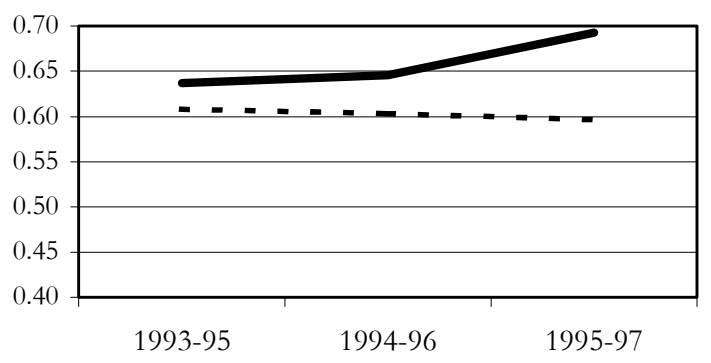

Portugal

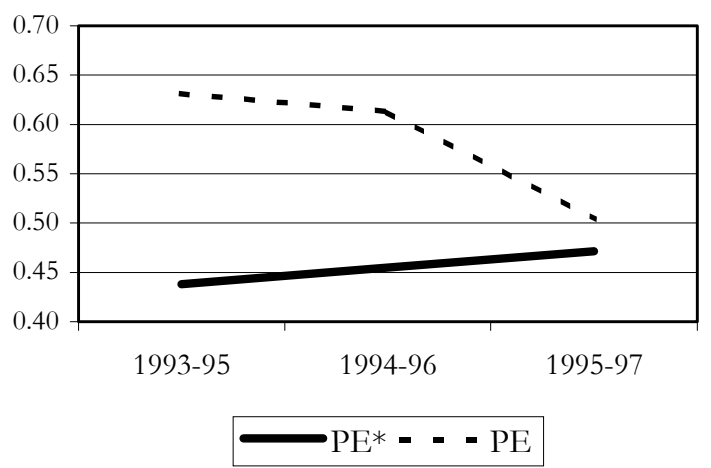

Source: IBCA Ltd. and own preparation 
Table 7: Ranking correlation

\begin{tabular}{lrrrrrr}
\hline & PE & PE* & CE & CE* $^{*}$ & ROA & TC/A \\
\hline PE & 1.000 & & & & & \\
PE* & 0.849 & 1.000 & & & & \\
CE & 0.129 & 0.279 & 1.000 & & & \\
CE* & 0.306 & 0.299 & 0.925 & 1.000 & & \\
ROA & 0.643 & 0.559 & 0.077 & 0.193 & 1.000 & \\
TC/ A & -0.079 & -0.082 & -0.117 & -0.110 & 0.214 & 1.000 \\
\hline
\end{tabular}

Note: PE: Profit efficiency, PE*: Risk adjusted profit efficiency,

CE: Cost efficiency, CE*: Risk adjusted cost efficiency,

ROA: Returns on total assets and TC/A: Total costs/Total assets.

Source: IBCA Ltd. and own preparation. 
- The correlation between the rankings of cost efficiency (adjusted for risk and unadjusted) and the ranking of average costs (TC/A) is negative, indicating that the most cost efficient banks, ceteris paribus, are those with lowest average costs.

- Similarly, there is a positive correlation between the rankings of profit efficiency (adjusted and unadjusted for risk, PE and $\mathrm{PE}^{*}$ ) and the ranking of returns (ROA) indicating that the most profit efficient banks, ceteris paribus, are the most profitable.

- The correlation between the rankings of average costs (TC/A) and profitability (ROA) is positive, i.e. the banks with highest average costs are also the most profitable, indicating that their higher costs, due in part to specialisation, are more than recovered through prices, enabling higher profitability.

The risk management efficiency indicators (RME) are presented in table 8. The first column reflects the average for the whole period, the next three columns the three sample periods considered, the first being made equal to 100. RME for the average of all the banks is $17.1 \%$, indicating that given the specialisation, given the environment, given the economic situation and the policy on granting credits, the banks of the countries of the EU considered could have decreased their bad debt by $82.9 \%$.

The situation by countries is very different. Most notable are the cases of Belgium and Luxembourg, where most bad debt is due to their poor risk management, as against the banks of the Portuguese banking system, which being the most efficient in risk management could only reduce its bad loans by $21 \%$ through increasing $\mathrm{RME}^{23}$.

Mortgage banks stand out for their high efficiency in risk management when comparing institutional groups. This result indicates, on the one hand, that specialising in the granting of loans gives them comparative advantages and/or that mortgage loans carry less implicit risk than other types of loans. There is a negative correlation between size and $\mathrm{RME}^{24}$.

To answer the question of whether banks' behaviour towards risk has changed, it is necessary to analyse the evolution over time. The results indicate that: 1) the sample of EU banks as a whole underwent a reduction of $22 \%$ in the level of RME; 2) except for the banks of Germany, Luxembourg and Portugal, there was a fall in the estimated levels of RME; 3) by

\footnotetext{
${ }^{23}$ The Portuguese banking system is the most efficient in risk management, but not the most cautious in credit policy as seen earlier.

${ }^{24}$ This result, contrary to that obtained by Pastor (1999a) for the case of Spain.
} 
Table 8: Risk management efficiency (RME)

\begin{tabular}{|c|c|c|c|c|}
\hline & \multirow{2}{*}{ 1993-97 } & \multicolumn{3}{|c|}{$1993-95=100$} \\
\hline & & 1993-95 & 1994-96 & 1995-97 \\
\hline Germany & 0.152 & 100.0 & 116.3 & 104.0 \\
\hline Belgium & 0.039 & 100.0 & 67.2 & 74.4 \\
\hline Spain & 0.151 & 100.0 & 47.2 & 39.9 \\
\hline France & 0.134 & 100.0 & 62.0 & 49.4 \\
\hline Italy & 0.225 & 100.0 & 66.6 & 65.1 \\
\hline Luxembourg & 0.010 & 100.0 & 70.8 & 251.9 \\
\hline Portugal & 0.795 & 100.0 & 100.3 & 113.5 \\
\hline Commencial banks & 0.141 & 100.0 & 93.5 & 83.7 \\
\hline Cooperatives & 0.232 & 100.0 & 68.0 & 75.5 \\
\hline Savings banks & 0.206 & 100.0 & 72.8 & 70.6 \\
\hline Mortgage & 0.700 & 100.0 & 120.0 & 121.4 \\
\hline Others $^{(1)}$ & 0.114 & 100.0 & 64.8 & 71.6 \\
\hline Small $^{(2)}$ & 0.292 & 100.0 & 72.6 & 71.3 \\
\hline Large $^{(3)}$ & 0.268 & 100.0 & 88.0 & 93.0 \\
\hline Very large $^{(4)}$ & 0.084 & 100.0 & 81.5 & 71.9 \\
\hline EU-7 & 0.171 & 100.0 & 83.1 & 78.3 \\
\hline Std. & 0.259 & - & - & - \\
\hline Coef. Var. & 1.521 & - & - & - \\
\hline
\end{tabular}

(1) Includes investment banks and specialized government banks.

(2) Banks with total assets less than 5 billions of U.S. dollars.

(3) Banks with total assets between 5 and 30 billions of U.S dollars.

(4) Banks with total assets over 30 billions of U.S. dollars.

Source: IBCA Ltd. and own preparation. 
institutional/specialisation groups, only mortgage banks improved their level of RME, despite being already the group with the highest level of RME; and 4) by sizes, the small banks and the very big ones experienced the greatest falls in RME levels.

To sum up, the above results show that the simple observation of the level of PLL presented in figure 1 is not a good indicator of banks' behaviour toward risk. Thus, although this ratio has had a downward trend over the period analysed, we cannot conclude that the banks have improved their risk management or that their policies are more cautious, since this indicator is contaminated by the effect of the favourable economic situation on bad loans. The obtaining of RME indicators that discount the effect of the economic situation has allowed us to reach a conclusion completely contrary to the one we would obtain from simple observation of the bad debt ratio in figure 1. Indeed, the results obtained indicate that RME fell over the period considered. However, in spite of this, total bad debt decreased fundamentally because this phenomenon occurred at a period of favourable economic circumstances.

The difference between the indicators of RME and the indicator of credit risk (PLL) is shown in figure 4. In part a) it can be observed that, even though efficiency in risk management (RME) has fallen, credit risk has fallen. In part b) we reach the same conclusion but in the context of a cross section. In this case, we see that the banking systems that are most efficient in risk management are not necessarily those that have least bad loans, and vice versa.

\section{CONCLUSIONS}

The implantation of the Euro in eleven of the fifteen countries of the EU has driven the big Community banks to expand their presence in other countries. However, penetrating new markets always involves acting at a disadvantage to the banks already established there. In this sense, inferior knowledge of the market, together with eagerness to expand market share, can produce either a wrong evaluation of credit risks, or a greater acceptance of them, and the bad loans of the big European banks could increase for these reasons.

To our knowledge, there is only one study (Pastor 1999b) devoted to analysing how the bad paper of the banking systems of the Euro area have responded to this new situation. The few studies at international level have concentrated on analysing efficiency without 
Figure 4: Credit risk (PLL) and risk management efficiency (RME)

a) Trend

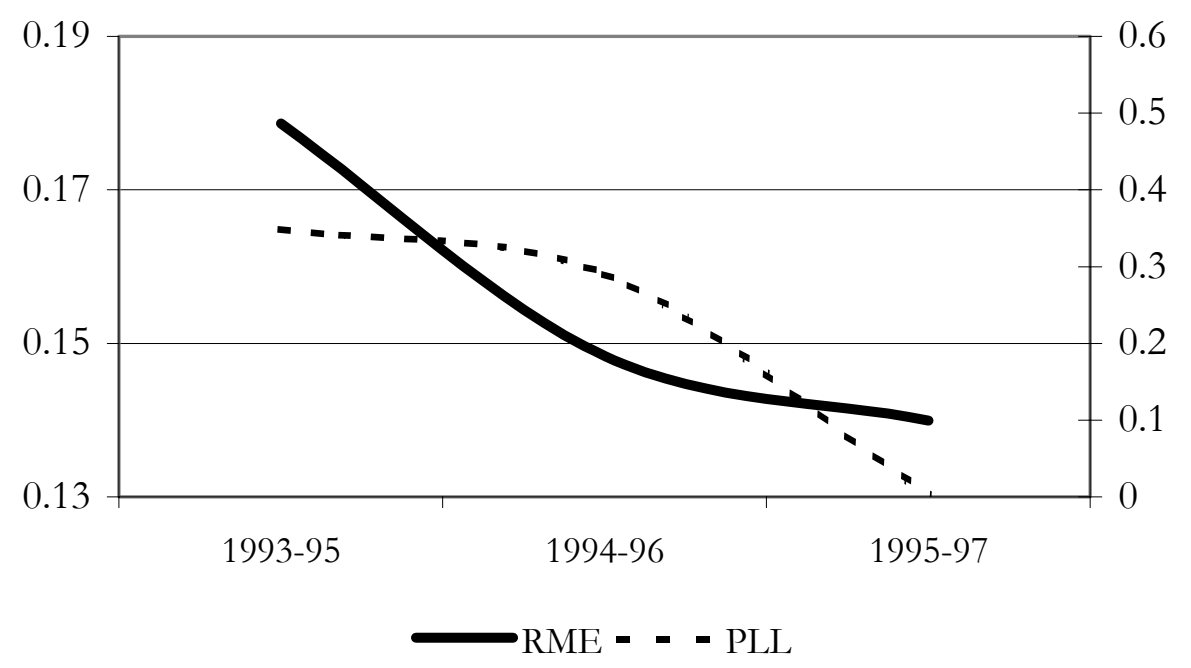

b) Average (1993-97)

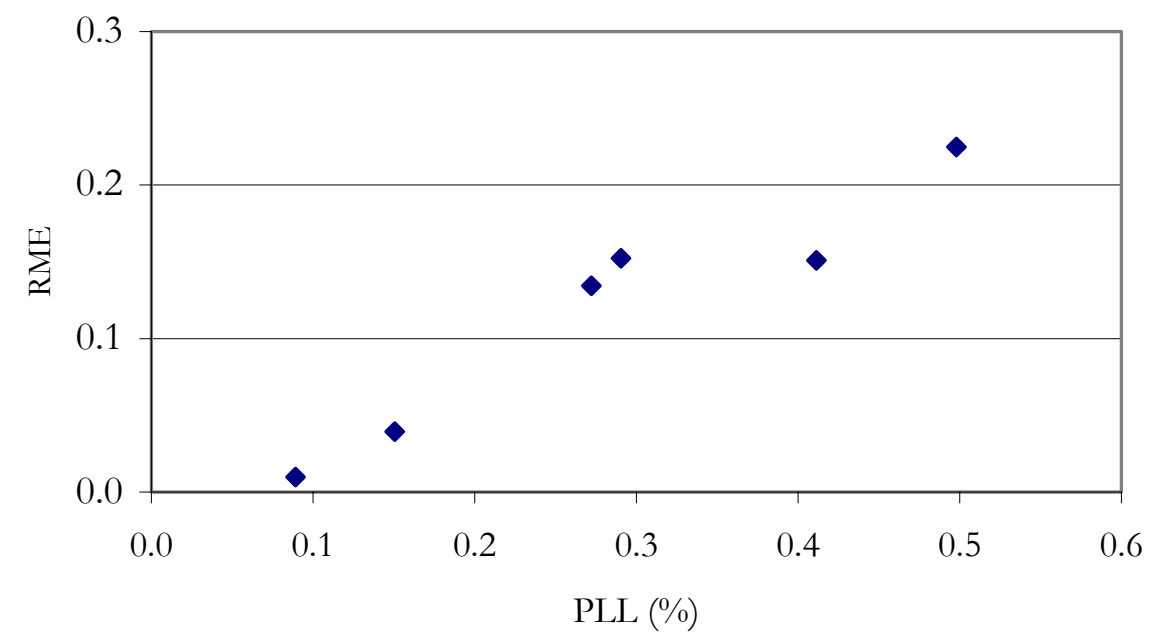

Notes: (1) RME= Risk management efficiency. Portugal has been excluded in panel b).

(2) Credit risk measured as provision for loan losses (PLL).

Source: IBCA Ltd. and own preparation. 
concerning themselves with the impact that these processes may have on bad loans, and the influence of bad loans on efficiency. However, the study by Pastor (1999b) is based on a laborious three stage procedure based on a deterministic technique and covers only up to the year 1995. In this sense, the aim of this study is to analyse the efficiency and the bad loans of the banks of the most important countries of the Euro area by developing a single stage parametric procedure. The procedure proposed allows it to be identified whether the behaviour towards risk of the banks analysed was more cautious or on the contrary more incautious during the period analysed.

The initial results, obtained by simple observation of the accounting ratios, revealed substantial heterogeneity among the banks forming the sample, more so on the profit side than on the cost side. Also, it is observed that higher costs do not necessarily imply lower profitability, but quite the opposite, indicating that the banks that operate with higher average costs can more than recover these high average costs through revenue and be at the same time the most profitable banking sectors.

The estimations, using the DFA technique, of the average levels of cost efficiency (CE) and profit efficiency (PE) and of the average levels of cost and profit efficiency adjusted for risk $\left(\mathrm{CE}^{*}\right.$ and $\left.\mathrm{PE}^{*}\right)$ offer the results commented on below.

For the whole sample, cost efficiency (EC) is $89.4 \%$. By countries, France and Luxembourg are the most efficient while Spain and Portugal are the most inefficient. In the analysis by institutions, the commercial banks are the most cost efficient while the savings banks are the least efficient. The results by size of firm reveals that it is the biggest firms that enjoy advantages in terms of cost efficiency.

The measurements of cost efficiency adjusted for risk $\left(\mathrm{CE}^{*}\right)$ hardly differ from the unadjusted measurements. Neither the level of efficiency, nor the rankings by country, institution or size, are significantly altered.

The average levels estimated for profit efficiency (PE) are lower than those for cost efficiency, which is indicative of the extreme importance of the revenue side, as made manifest in other studies. The ranking by countries is also different: whereas France was the most cost efficient country, it is the least profit efficient. Similarly, Spain and Portugal were the most inefficient in costs and are the most efficient in profits.

The profit efficiency adjusted for risk $\left(\mathrm{PE}^{*}\right)$ are higher than those of $\mathrm{PE}$, making it clear once again that it is from the profit viewpoint that behaviour towards risk really matters. With regard to evolution over time, it is worth noting that cost and profit efficiency adjusted 
for risk is very stable over the whole period. Also, in all the countries profit efficiency is lower than cost efficiency.

Efficiency in risk management (RME) for the average of the sample is $17.1 \%$. The situation by countries is very different. Luxembourg and Belgium are very inefficient and Portugal very efficient. By institutional groups, the high efficiency in risk management of the mortgage banks stands out. The sample of banks of the EU experienced a reduction of $22 \%$ in RME, indicating that the behaviour of the banks is less careful than at the start of the period. Except the banks of Germany, Luxembourg and Portugal, the other banking systems undergo a fall in the estimated levels of RME. By institutional groups, only the mortgage banks improved their levels of RME, despite already being the institutional group with highest initial level of RME. By sizes, it is the small banks and the very big ones that experience the steepest falls in RME levels. 
APPEN DIX: Economic cycle variables $\left(\mathrm{X}^{\mathrm{EXT}}\right)$, intemal $\left(\mathrm{X}^{\mathrm{INT}}\right)$ and environmental $\left(\mathrm{X}^{\mathrm{AMB}}\right)$

\begin{tabular}{|c|c|c|}
\hline \multicolumn{3}{|c|}{ E conomic cycle variables $\left(\mathrm{X}^{\mathrm{EXT}}\right)$} \\
\hline GDP per capita & $-4.1 \mathrm{E}-07$ & -13.42 \\
\hline Real interest rates(1) & $2.1 \mathrm{E}-04$ & 2.50 \\
\hline Inflation rate & $-1.5 \mathrm{E}-03$ & -9.09 \\
\hline Unemployment rate & $-2.3 \mathrm{E}-04$ & -11.24 \\
\hline \multicolumn{3}{|c|}{ Intemal variables $\left(\mathrm{X}^{\mathrm{INT}}\right)$} \\
\hline Loans/ Assets & $2.2 \mathrm{E}-03$ & 7.13 \\
\hline Interest income/ Assets & $1.3 \mathrm{E}-01$ & 23.01 \\
\hline \multicolumn{3}{|c|}{ Environmental variables $\left(\mathrm{X}^{\mathrm{AMB}}\right)$} \\
\hline$\overline{\text { ATMs/ branches }}$ & $8.5 \mathrm{E}-01$ & $\overline{12.82}$ \\
\hline Branches/ number of firms & $1.3 \mathrm{E}-03$ & 3.57 \\
\hline ATMs/ population & $-5.1 \mathrm{E}-02$ & -0.46 \\
\hline Assets/ branches & 3.6E-04 & 10.14 \\
\hline$\gamma$ & $2.1 \mathrm{E}+02$ & 18.57 \\
\hline
\end{tabular}

(1) Short-term interest rates. 


\section{REFERENCES}

Allen, L. and Rai, A. (1996): "Operational Efficiency in Banking: An International Comparison". Journal of Banking and Finance 20, 665-72.

Bauer, P.W., A.N. Berger, G.D. Ferrier and D.B. Humphrey (1998): "Consistency conditions for regulatory analysis of financial institutions: a comparison of frontier efficiency methods”, Journal of Economics and Business 50 (2), 85-114..

Barr, R. and T. Siems (1994): "Predicting bank failure using DEA to quantify management quality", Federal Reserve Bank of Dallas, Financial Industries Studies Working Paper 1-94. January.

Becher, D. R., R. De Young and T. Lutton (1995): "Projecting resolved assets in banks: A comparison of different methods", Office of the Comptroller of the Currency, Working Paper.

Berg, S.A., P.N.D. Bukh and F.R. Førsund (1995): "Banking Efficiency in the Nordic Countries: A Four Country Malmquist Index Analysis”, Working Paper, University of Aarhus, Denmark (September).

Berg, S.A., F.R. Førsund. L. Hjalmarson and M. Suominen (1993): "Banking Efficiency in the Nordic Countries", Journal of Banking and Finance 17, 371-88.

Berger, A.N. and D.B. Humphrey (1991): "The dominance of inefficiencies over scale and product mix economies in banking", Journal of Monetary Economics 28, pp. 117- 148.

Berger, A.N. and D.B. Humphrey (1992): "Measurement and efficiency issues in commercial banking", pp. 24-79 in Z. Griliches, ed., Output Measurement in the service sectors, National Bureau of Economic Research, Studies in Income and Wealth, vol. 56, Chicago: University of Chicago Press.

Berger, A.N., D. Hancock, D. and D.B. Humphrey (1993): "Bank efficiency derived from the profit function", Journal of Banking and Finance 17, 317-347.

Berger, A.N. and R. De Young (1997): "Problem Loans and cost efficiency in commercial banks", Journal of Banking and Finance 21, 849-870. 
Berger, A.N. and L. J. Mester (1997): "Inside the black box: What explains differences in the efficiencies of financial institutions", Journal of Banking and Finance 21, 895947.

Berghendahl, G. (1995): "DEA and Benchmarks for Nordic Banks", Working Paper, Gothenburg University, Gothenberg, Sweden (December).

Fecher, F. and P. Pestieau (1993): "Efficiency and Competition in O.E.C.D. Financial Services “ in H.O. Fried, C.A.K. Lovell, and S.S. Schmidt, eds., Measurement of Productive Efficiency: Techniques and Applications, (Oxford University Press), U.K., 364-85.

Hughes, J. P., and L. Mester (1993): “A quality and risk-adjusted cost function for banks: Evidence on the 'Too-Big-To-Fail' doctrine”, The Journal of Productivity Analysis 4, 293-315.

Maudos, J., J.M. Pastor, F. Pérez and J. Quesada (2000): "Cost and profit efficiency in the European Banks”, Journal of International Financial Martet Institutions and Money (forthcoming).

Mester, L. (1994a): "How efficient are third district banks?", Federal Reserve Bank of Philadelphia, Business Review, January.

Mester, L. (1994b): "Efficiency of banks in the third district", Federal Reserve Bank of Philadelphia, Working Paper 94-1.

Pastor, J.M. (1998): "Gestión de riesgo y eficiencia en los bancos y cajas de ahorro", Documento de trabajo 142/1998. Fundación FIES

Pastor, J.M. (1999a): "Efficiency and risk management in Spanish banking firms: A method to decompose risk", Applied Financial Economics 9(4), pp. 371-384.

Pastor, J.M. (1999b): "Credit risk and efficiency in the European banking systems: A threestage analysis", WP-EC 99-18. Instituto Valenciano de Investigaciones Económicas (IVIE)

Pastor, J.M., F. Pérez and J. Quesada (1995): “Are European Banks Equally Efficient?”, Belgian Journal of Banking and Finance (Revue de la Banque). June, 324-323. 
Pastor, J.M., F. Pérez and J. Quesada (1997a): "Efficiency Analysis in Banking Firms: An International Comparison”, European Journal of Operational Research 98, 395-407

Pastor, J.T., A. Lozano and J.M. Pastor (1997b): "Efficiency of European Banking Systems: A correction by environmental variables" Working Paper IVIE WP-EC 9712.

Rogers, K.E. (1998): "Nontraditional activities and the efficiency of US commercial banks", Journal of Banking and Finance 22, 467-482.

Saurina, J. (1998): "Determinantes de la morosidad de las cajas de ahorro españolas", Investigaciones Económicas, vol. 22(3), 393-426

Saurina, J. (1999): "Existe alisamiento del beneficio en las cajas de ahorros españolas?", III Foro de Finanzas de Segovia.

Simar, L. (1992): "Estimating efficiencies from frontier models with panel data: a comparison of parametric, non-parametric and semi-parametric methods with bootstrapping", Journal of Productivity Analysis 3, 171-203.

Toevs, A. and R. Zizka (1994): "Is Your Bank Inefficient? Standard Ratios Often Lie", American Banker, April, 20 \& 24.

Wheelock, D.C. and P.W. Wilson (1995): "Explaining bank failures: Deposit Insurance regulation and efficiency", Review of Economics and Statistics 77(4), November, 689700 . 